\title{
Effect of Acibenzolar-S-methyl and Rahnella aquatilis (Ra39) on Chitinase and $\beta-1,3$-glucanase Activities and Disease Resistance of Apple Plants
}

\author{
A. M. Kamal Abo-Elyousr' ${ }^{1 *}$, M. A. A. Sallam ${ }^{1}$, M. H. A. Hassan ${ }^{1}$ and W. Zeller ${ }^{2}$ \\ ${ }^{1}$ Dept. of Plant Pathology Faculty of Agriculture, Assiut Univ., Assiut, Egypt \\ ${ }^{2}$ Institut für biologischen Pflanzenschutz, Heinrichstr 243, 64287 Darmstadt, Germany \\ (Received on October 11, 2009; Accepted on February 12, 2010)
}

The effect of Acibenzolar-S-methyl (ASM) and Rahnella aquatilis Ra39 against apple fire blight disease caused by Erwinia amylovora were tested as a possible alternative to streptomycin. In vitro studies, no inhibition effect against the pathogen was found when ASM was tested. Under greenhouse conditions, application of $\boldsymbol{R}$. aquatilis Ra39 with the highly susceptible M26 rootstock resulted in a marked disease suppression. Application of ASM and strain Ra39 caused a high decrease of the disease, $82 \%$ and $58 \%$ respectively; this was correlated with a reduction of the growth of the pathogen within host plants up to $64 \%$ and $49.5 \%$ respectively. Further studies in the field under artificial infection condition during full bloom revealed that application of ASM and $R$. aquatilis Ra39 with Gala variety resulted in a control effect up to 21 and $29 \%$ respectively. In physiological studies, enhanced activities of PR-proteins (chitinase and $\beta$-1,3-glucanase) were detected, which are well known as biochemical markers for systemic acquired resistance. Application of ASM to apple shoots caused the highest chitinase activity followed by strain Ra39. The enzyme activity was increased after 2, 4 and 6 days from application. In addition, ASM-treatment caused the higher $\beta-1,3$-glucanase activity than strain Ra39. Maximum enzyme activity was recorded after 6 days from application and then decreased after 8 and 10 days from application.

Keywords : fire blight, acibenzolar-S-methyl, Rahnella aquatilis, PR-proteins

Fire blight has been known as a destructive disease of apple and pear for over 200 years. The disease is caused by the bacterium Erwinia amylovora (Burrill) Winslow et al. It has been reported from 40 countries around the world and caused serious losses to pome fruits and ornamentals plants, especially Rosaceae family (Vanneste, 2000). In Egypt, during early of 1980 , the disease became very severe, and about $80 \%$ of all pear acreage was affected and $50 \%$ of all

\footnotetext{
*Corresponding author.

Phone) +20882412726, FAX) +20882331384

E-mail)kaaboelyousr@yahoo.com
}

trees had been eradicated, presumably due to an increase in rain during the blooming period (El-Kazzaz, 1992).

At present, the disease is controlled by application of various methods including sanitation, chemical treatment, selection of resistance cultivars and soil management. However, there is no single mean that would totally eradicate the disease, provide an absolute cure or fully protect host plants against infection.

Generally, only copper and antibiotics preparations are recommended but their use has some limitations. The antibiotics have lead to the selection of resistance bacterial populations. Therefore, their use is strictly limited or even forbidden in a number of countries. The copper compounds usually cause phytotoxicity in fruit and therefore, cannot be used for high quality fruits (Paulin, 1996; Sobiczewski et al., 2001). In addition, none of these chemicals is systemic, and to be effective, they have to be applied with through coverage before the pathogen enters the plant tissues.

The newest control method for controlling fire blight disease is the use of induction of systemic acquired resistance (SAR). Several biocontrol agents have been showed to induce resistance in plants. Biotic and chemical agents are reported as SAR inducers, such as fungi, bacteria, viruses, metabolites of pathogens, plant extract, etheric oils and synthetic compound (Dietrich et al., 1999).

One of synthetic compounds is acibenzolar-S-methyl $\left(\mathrm{ASM}\right.$, Bion $\left.^{\circledR}\right)$ which activates treated plants to produce pathogenesis-related proteins (PR-Proteins) in intercellular spaces. They are able to degrade bacterial cell walls. ASM cause SAR since it mimics the role of salicylic acid (Kessmann et al., 1996; Sobiczewski et al., 2001). It was found that the best period of Bion ${ }^{\circledR}$ application as fire blight resistance inducer on apples was two days suspected infection (Baysal and Zeller, 2004).

Several epiphytic bacteria have been also reported to induce resistance against certain plant diseases (Goodman et al., 1986). Biocontrol strains, an inducer of resistance were shown to cause physiological changes in plants. Thus, enhanced level of PR-proteins (chitinase and $\beta-1,3$ glucanase) which can be regarded as markers of induced resistance were observed. PR proteins have been identified 
and include $\beta$-1, 3-glucanases (PR-2) which posses direct antimicrobial activity by degrading microbial cell wall components (Baysal and Zeller, 2004), chitinases have lysozyme activity and can therefore hydrolyse bacterial cell walls (Heitz et al., 1994).

The present work was planned to study the effect of Acibenzolar-S-methyl (ASM) and Rahnella aquatilis Ra39 on incidence of fire blight disease caused by E. amylovora under greenhouse and field conditions as well as pathogen population within the host plants. The effect of such resistance inducers on certain physiological processes in host plants was also investigated.

\section{Materials and Methods}

Effect of Acibenzolar-S-methyl (ASM) and Rahnella aquatilis Ra39 on fire blight causal organisms in vitro. For accomplished this test, Miller-Schroth medium (MSM) was used. ASM and Ra39 were tested for their effect on growth of E. amylovora isolates Ea 7/74. The agar diffusion test medium was used to accomplish such test. A suspension of Ea 7/74 spread over agar surface and after drying, ASM and $10^{8}$ colony forming units (CFU)/ml of Rahnella aquatilis Ra39 were pipetted into $9 \mathrm{~mm}$ punched. The antibiotic streptomycin was used as a comparison. After 3 days of incubation periods at $27^{\circ} \mathrm{C}$, inhibition zones were measured $(\mathrm{cm})$.

Bacterial strain and inoculation. Bacterial isolates of $E$. amylovora $\mathrm{E} 7 / 74$ and $R$. aquatilis Ra39 were obtained from the stock cultures of Institut für biologischen Pflanzenschutz, Heinrichstr. 243, 64287 Darmstadt, Germany. Inoculum was prepared from early log-phase cells by growing the bacterial isolates in nutrient yeast extract broth medium in $25 \mathrm{ml}$ sterile tubes, incubated at $25^{\circ} \mathrm{C}$ on an orbital shaker at $200 \mathrm{rpm}$ for $24 \mathrm{hr}$. Bacteria were subsequently pelleted by centrifugation at $15,000 \mathrm{rpm}$ at $4{ }^{\circ} \mathrm{C}$ for $5 \mathrm{~min}$ and washed in saline. Concentration of bacterial suspension was adjusted to $10^{7}$ colony forming units $(\mathrm{CFU}) / \mathrm{ml}$. Inoculation was carried out with Ea7/74 using a hand mist sprayer at a concentration of $1 \times 10^{7} \mathrm{CFU} / \mathrm{ml}$ control plants were treated similarly with bacterium free solution. Evaluation of diseases severity was assessed after 16 days from inoculation according to a rating system from 0-10 whereas 0 -no obvious symptom and minimum necrosis at the cutting point was assessed as no symptom, as it sometimes also occurred in control plants. 10-infection of shoot, often together turning black, and shoot curved Mosch et al. (1993). Disease index (DI) was calculated from each treatment by

$$
\text { DI } \%=\frac{(\text { Number of leaves } \times \text { class of symptom })}{\text { Total number of leaves } \times 10} \times 100
$$

Application of ASM and Ra39 under greenhouse condition. (benzo(1,2,3)thiadiazole-7-carbothioic acid S-methyl ester), acibenzolar-S-methyl (ASM), the commercial name, Bion $^{\circledast}$, was obtained from Novartis, Basel, Switzerland and used at a concentration of $0.05 \%$ (diluted with tap water) as abiotic inducing agents by spraying on apple rootstocks at $48 \mathrm{hr}$ before inoculation as well as the saprophytic bacterium, $R$. aquatilis Ra39 was used at $10^{8} \mathrm{CFU} / \mathrm{ml}$ as biotic agent. It was cultured in nutrient yeast extract broth medium and incubated for $48 \mathrm{hr}$ and then centrifuged. The pellet was transferred into an Erlenmeyer flask with $10 \mathrm{ml}$, of sterile $0.85 \% \mathrm{NaCl}$ solution. The bacterial suspension was diluted to an optical density of 0.2 with a spectrophotometer (Spectronic $^{\mathrm{R}} 20$ Genesys $^{\mathrm{TM}}{ }^{\mathrm{T}}$, Schutt labortechink) at a wavelength of $660 \mathrm{~nm}$ with $\mathrm{NaCl}$ solution as reference. This yielded a bacterial suspension of $10^{8} \mathrm{CFU} / \mathrm{ml}$ concentrations. The treatments sprayed on apple rootstock two day before inoculation by E. amylovora. Three replicates were used, 12 plants for each treatment and repeated twice.

Application of ASM and Ra39 under field conditions. ASM and Ra39 were tested for controlling blossom fire blight disease of apple caused by E. amylovora under artificial infected conditions on Gala apple variety. These experiment were carried out during 2001/02 and 2002/03 seasons at the Experimental Farm of BBA Institute, Darmstadt, Germany. ASM and Ra39 were sprayed on apple plants at rates equivalent to $0.05 \%$ for ASM, and $1 \times 10^{8}$ $\mathrm{CFU} / \mathrm{ml}$ bacterial suspensions. One liter of ASM and Ra39 suspensions were sprayed near to runoff one day before inoculation. Seven replicates were used for each treatment which it contained 4 trees. Artificial inoculation was carried out with Ea7/74 using a hand mist sprayer at a concentration of $1 \times 10^{7} \mathrm{CFU} / \mathrm{ml}$. Control plants were treated similarly with water. Evaluation of disease development was recorded 5 weeks after inoculation.

Determination of bacterial population in vivo. For the determination of bacterial multiplication within the host plants, samples of apple shoot tips (ca. one gm) were homogenized in a $0.06 \% \mathrm{NaCl}$ solution. From each homogenate, a dilution plating $\left(10^{1}\right.$ to $\left.10^{6}\right)$ was prepared on modified Miller-Schroth medium (MSM) for E. amylovora Ea7/74 (Zeller and Brulez, 1987). Three replicates were used in this experiment.

PR-Proteins activities (Chitinase and $\boldsymbol{\beta}$-1, 3-glucanase) assay. The effect of ASM and Ra39 on biochemical changes of inoculated by E. amylovora and non-inoculated apple rootstocks were studied in greenhouse. Three months old M26 rootstocks were sprayed with ASM and Ra39 inducers two days before inoculation with Ea7/74. The 
samples were collected after 2, 4, 6, 8 and 10 days from application and also after inoculation by the tested bacterium to determine PR-protiens.

Chitinase and $\beta$-1, 3-glucanase activities were determined using the method described by Wirth and Wolf (1992). High polymeric carbomethyl-substituted chitin labeled covalently Remazol Brilliant Violet 5R (CM-Chitin*-RBV. Comp. Loewe Biochemica) was used as substrate for chitinase activity while polymeric carbomethyl-substituted curdlan labeled covalently with Remazol Brilliant Violet 5R (CM-Curdlan*-RBV. Comp. Loewe Biochemica) was used as substrate for $\beta-1,3$-glucanase activity. The reaction mixture was as follows:

$0.50 \mathrm{ml} 0.01 \mathrm{M} \mathrm{Na}$-Acetate buffer $\mathrm{pH} 5.2$ with $5 \%(\mathrm{v} / \mathrm{v})$ Glycerine, $0.25 \mathrm{ml}$ plant extract and $0.25 \mathrm{ml}$ dye labeled substrate CM-*RBV solution $(2 \mathrm{mg} / \mathrm{ml})$. Test samples were incubated in a water bath at $37^{\circ} \mathrm{C}$ for $120 \mathrm{~min}$. for determination of chitinase activity and $60 \mathrm{~min}$ for determination of $\beta-1,3$-glucanase activity. The enzyme reaction was terminated by adding $0.25 \mathrm{ml} 2 \mathrm{~N} \mathrm{HCl}$. After centrifugation $(14,000 \mathrm{rpm} ; 5 \mathrm{~min})$, supernatants containing soluble, dye labeled degradation products were transferred to another cuvettes. Absorbency was measured spectrophotometrically at $550 \mathrm{~nm}$ (chitinase) or $600 \mathrm{~nm}$ ( $\beta$-1, 3-glucanase) sodium acetate buffer was added to blanks instead of plant extract. Enzyme activity was expressed as enzyme unit/mg protein. The total protein content of apple shoots was determined according to the method described by Bradford (1976).

Each sample of extract was measured twice in each replicate, and at least three replications were preformed per analysis.

Statistical analysis. All greenhouse experiments were arranged in a completely randomized split-plot design with three replicates of 12 plants for each treatment and repeated twice. Each sample of extract was measured twice in each replicate, and at least three replications were performed per analysis. The significance of differences between mean values was determined. Analysis of variance (ANOVA) was carried out, and the significance of differences among the treatments was determined according to Least Significant Difference L.S.D. (Gomez and Gomez, 1984).

\section{Results}

Effect of Acibenzolar-S-methyl (ASM) and $R$. aquatilis Ra39 on fire blight causal organisms in vitro. Results in Table 1 showed that ASM did not inhibit of E. amylovora. However, streptomycin and Ra 39 showed an inhibitory effect on E. amylovora.

Effect of ASM and Ra39 on fire blight causal organisms
Table 1. Effect of Acibenzolar-S-methyl (ASM) and R. aquatilis Ra39 on growth of E. amylovora Ea7/74 on agar diffusion test

\begin{tabular}{cc}
\hline \hline Treatments & Inhibition Zone $(\mathrm{cm})$ \\
\hline ASM & $0.0 \mathrm{c}$ \\
Ra39 & $0.2 \mathrm{~b}$ \\
Streptomycin & $0.5 \mathrm{a}$ \\
\hline
\end{tabular}

Values in the column followed by different letters indicate significant differences among treatments according to LSD test at 0.05 .

Table 2. Population of E. amylovora in shoots of apple rootstock M26 after treatment with Acibenzolar-S-methyl (ASM) and $R$. aquatilis Ra39

\begin{tabular}{ccccc}
\hline \hline \multirow{2}{*}{$\begin{array}{c}\text { Days after } \\
\text { application }\end{array}$} & \multicolumn{4}{c}{ Treatments } \\
\cline { 2 - 5 } & Ra39 & ASM & Control & Mean \\
\hline 4 & $1.05 \mathrm{c}$ & $0.25 \mathrm{c}$ & $2.45 \mathrm{~b}$ & $1.23 \mathrm{c}$ \\
7 & $3.80 \mathrm{a}$ & $3.75 \mathrm{a}$ & $1.50 \mathrm{c}$ & $5.84 \mathrm{a}$ \\
11 & $2.80 \mathrm{~b}$ & $3.10 \mathrm{~b}$ & $7.25 \mathrm{a}$ & $4.28 \mathrm{~b}$ \\
15 & $2.90 \mathrm{~b}$ & $3.80 \mathrm{a}$ & $7.30 \mathrm{a}$ & $4.50 \mathrm{~b}$ \\
\hline
\end{tabular}

The samples of apple shoot tips (ca. one gm) were homogenized in a $0.06 \% \mathrm{NaCl}$ solution. From each homogenate, a dilution plating $\left(10^{1}\right.$ to $10^{6}$ ) was prepared on modified Miller-Schroth medium (MSM) for E. amylovora Ea7/74. Three replicates were used in this experiment. Values in the column followed by different letters indicate significant differences among treatments according to LSD test at 0.05 .

in vivo. Results in Table 2 showed that ASM and Ra39 significantly reduced the number of the E. amylovora cells as compared with the control. Results also indicated that after 4 days, ASM showed the higher reduction in growth of the pathogen within the host than strain Ra39. Data also indicated that strain Ra39 was the best in reduction of the pathogen than those of ASM after 11 and 15 days.

Effect of ASM and Ra39 on fire blight incidence of apple under greenhouse conditions. Data of this experiment are presented in Fig. 1 indicated that untreated plants showed a significantly faster fire blight symptoms development for all tested days from inoculation. At 4 and 6 days post inoculation treatments, ASM and Ra39 significantly reduced the disease index. In generally, ASM showed the highest reduction in disease index followed by $R$. aquatilis Ra39 after all tested inoculation periods.

Effect of ASM and Ra39 on fire blight incidence of apple under field conditions. The effect of application of ASM and Ra39 on apple trees variety Galla, on controlling blossom fire blight disease caused by E. amylovora was studied in field in 2002 and 2003 successive seasons in the Experimental Farm of BBA Institute, Darmstadt, Germany. Results of these experiments are presented in (Fig. 2). The results indicated that application of ASM reduction the disease severity since treated plants showed lower percent- 


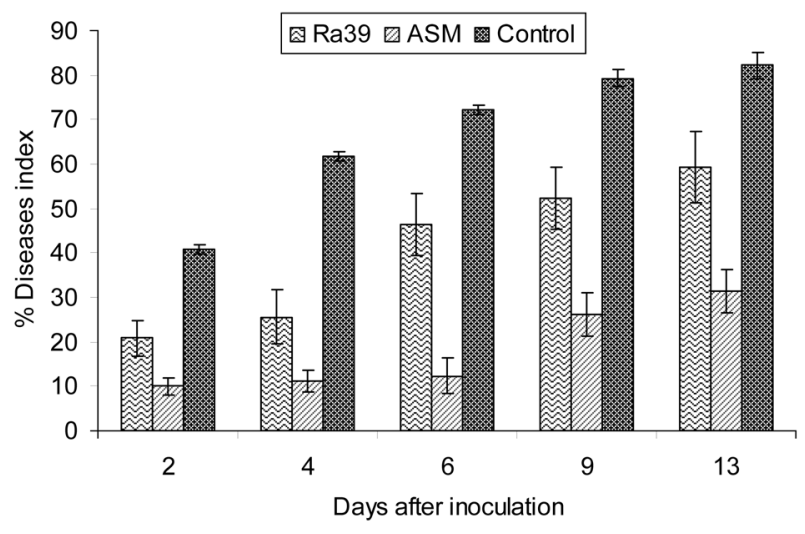

Fig. 1. Disease index of fire blight disease on apple rootstocks M26 after treatments with Acibenzolar-S-methyl (ASM) and $R$. aquatilis Ra39. ASM used at a concentration of $0.05 \%$ (diluted with tap water) by spraying on apple rootstocks at $48 \mathrm{hr}$ before inoculation and $R$. aquatilis Ra39 was used at $10^{8} \mathrm{CFU} / \mathrm{ml}$. Means of standard deviation for eight plants per treatment are shown.

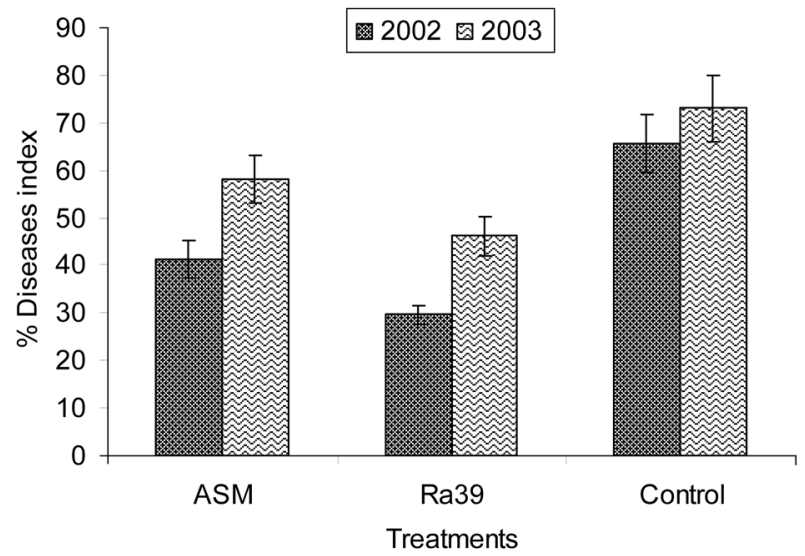

Fig. 2. Disease index of fire blight disease on apple variety Galla after treatments with Acibenzolar-S-methyl (ASM) and R. aquatilis Ra39. ASM and Ra39 were sprayed on apple plants at rates equivalent to $0.05 \%$, and $1 \times 10^{8} \mathrm{CFU} / \mathrm{ml}$ bacterial suspensions, respectively. One liter of ASM and Ra39 suspensions were sprayed near to runoff one day before inoculation. Seven replicates were used for each treatment which it contained 4 trees. Artificial inoculation was carried out with Ea7/74 using a hand mist sprayer at a concentration of $1 \times 10^{7} \mathrm{CFU} / \mathrm{ml}$. Control plants were treated similarly with water. Evaluation of disease development was recorded 5 weeks after inoculation. Means of standard deviation for eight plants per treatment are shown.

age of infection than the untreated control plants. Data also revealed that application of Ra39 caused higher disease reduction than those of ASM.

Chitinase activity. In non-inoculated shoots data presented in Table 3 indicated that treated apple shoots with ASM and Ra39 exhibited enzyme activity higher than the untreated control after all tested periods of enzyme determination especially at 6 days after application. In general, application
Table 3. Effect of Acibenzolar-S-methyl (ASM) and R. aquatilis Ra39 on activity of chitinase in inoculated and non-inoculated apple shoots

\begin{tabular}{ccccccccc}
\hline \hline \multirow{2}{*}{$\begin{array}{c}\text { Days after } \\
\text { inoculation }\end{array}$} & \multicolumn{2}{c}{ Non inoculated shoots } & & \multicolumn{3}{c}{ Inoculated shoots } \\
\cline { 2 - 3 } \cline { 7 - 8 } & Ra39 & ASM & Control & & Ra39 & ASM & Control \\
\hline 2 & $0.24 \mathrm{c}$ & $0.30 \mathrm{bc}$ & $0.18 \mathrm{~d}$ & & $0.60 \mathrm{c}$ & $0.65 \mathrm{~b}$ & $0.48 \mathrm{c}$ \\
4 & $0.50 \mathrm{~b}$ & $0.48 \mathrm{~b}$ & $0.39 \mathrm{c}$ & & $0.85 \mathrm{ab}$ & $0.86 \mathrm{bc}$ & $0.66 \mathrm{~b}$ \\
6 & $1.07 \mathrm{a}$ & $1.00 \mathrm{a}$ & $0.39 \mathrm{c}$ & & $1.22 \mathrm{a}$ & $1.61 \mathrm{a}$ & $0.75 \mathrm{a}$ \\
8 & $0.58 \mathrm{~b}$ & $0.69 \mathrm{~b}$ & $0.24 \mathrm{c}$ & & $0.91 \mathrm{ab}$ & $0.93 \mathrm{ab}$ & $0.67 \mathrm{~b}$ \\
10 & $0.23 \mathrm{c}$ & $0.43 \mathrm{~b}$ & $0.15 \mathrm{~d}$ & & $0.53 \mathrm{~cd}$ & $0.62 \mathrm{~b}$ & $0.40 \mathrm{c}$ \\
\hline
\end{tabular}

The values indicate Enzyme units

The samples were collected from both inoculated and non-inoculated plants after 2, 4, 6, 8 and 10 days after treatment). Values in the column followed by different letters indicate significant differences among treatments according to LSD test at 0.05 .

with ASM to apple shoots caused the higher enzyme activity than Ra39. The enzyme activity was increased after 2, 4 and 6 days from application and then decreased after 8 and 10 days from application.

In inoculated shoots, apple shoots treated by ASM and Ra39 exhibited higher chitinase activity than that of inoculated untreated control after all tested periods of determination. Maximum enzyme activity was recorded after 6 days from inoculation and then decreased for all tested treatments and ASM treatments caused the higher enzyme increase than Ra39.

$\beta-1,3$-glucanase activity. In non-inoculated shoots results presented in Table 4 indicated that $\beta$-1, 3-glucanase activity of non-inoculated apple shoots treated with ASM and Ra39 were significantly higher than that of untreated control after 4, 6 and 8 days from application. Highest enzyme activity for all treatments was detected after 6 days from application and then insignificantly decreased after 8 and 10 days from application. In general, ASM treatment caused the higher host enzyme activity than those caused by Ra39. Maximum enzyme activity was recorded after 6 days from application and then decreased after 8 and 10 days from application.

In inoculated shoots, the results showed that no significant differences were found in enzyme activity of all tested treatments after 2 days, also, diseased apple shoots treated with ASM and Ra39 exhibited significant higher $\beta-1,3-$ glucanase activity than that of diseased untreated control after 4,6 and 8 days from inoculation.

\section{Discussion}

From our first findings, no direct effect of Bion (ASM) on the pathogen, in vitro, which served as a first indication for using such compounds and the bacteria to induce acquired resistance in plants. These results are agreed with those 
Table 4. Effect of Acibenzolar-S-methyl (ASM) and R. aquatilis Ra39 on activity of $\beta$-1,3-glucanase in inoculated and noninoculated apple shoots

\begin{tabular}{ccccccccc}
\hline \hline \multirow{2}{*}{$\begin{array}{c}\text { Days after } \\
\text { inoculation }\end{array}$} & \multicolumn{3}{c}{ Non inoculated shoots } & & \multicolumn{3}{c}{ Inoculated shoots } \\
\cline { 2 - 3 } \cline { 7 - 9 } & Ra39 & ASM & Control & & Ra39 & ASM & Control \\
\hline 2 & $0.17 \mathrm{~d}$ & $0.22 \mathrm{c}$ & $0.19 \mathrm{~d}$ & & $0.16 \mathrm{~d}$ & $0.19 \mathrm{~d}$ & $0.16 \mathrm{~d}$ \\
4 & $0.49 \mathrm{ab}$ & $0.54 \mathrm{a}$ & $0.21 \mathrm{c}$ & & $0.64 \mathrm{~b}$ & $0.60 \mathrm{~b}$ & $0.29 \mathrm{c}$ \\
6 & $0.55 \mathrm{a}$ & $0.62 \mathrm{a}$ & $0.24 \mathrm{c}$ & & $0.90 \mathrm{a}$ & $1.00 \mathrm{a}$ & $0.27 \mathrm{c}$ \\
8 & $0.50 \mathrm{a}$ & $0.54 \mathrm{a}$ & $0.26 \mathrm{c}$ & & $0.62 \mathrm{~b}$ & $0.79 \mathrm{~b}$ & $0.24 \mathrm{c}$ \\
10 & $0.36 \mathrm{c}$ & $0.33 \mathrm{~b}$ & $0.28 \mathrm{c}$ & & $0.18 \mathrm{~d}$ & $0.24 \mathrm{c}$ & $0.17 \mathrm{~d}$ \\
\hline
\end{tabular}

The value indicate Enzyme units

The samples were collected from both inoculated and non-inoculated plants after 2, 4, 6, 8 and 10 days after treatment). Values in the column followed by different letters indicate significant differences among treatments according to LSD test at 0.05 .

reported by Siegrist et al. (1997); Zeller and Zeller (1999). ASM has been developed as a systemic acquired resistance (SAR) activator against fungal, bacterial and viruses diseases (Colson-Hanks et al., 2000; Abo-Elyousr et al., 2008; Abo-Elyousr and El-Hendawy, 2008), it doesn't antimicrobial properties, but instead increase crop resistance to diseases by activating the SAR signal transduction pathway.

In greenhouse experiments, severity of fire blight symptoms development in plants after application of tested resistance inducers was recorded. For all tested periods after treatment by ASM and Ra39, the disease index reduced greatly than the control plants. These results agree with those reported by Siegrist et al. (1997); Maxson-Stein et al. (2002); Zeller and Laux (2002); Abo-Elyousr and ElHendawy (2008); who mentioned that ASM could reduce the diseases severity of bacterial diseases under greenhouse and field conditions. Also, our results indicated that Ra39 reduce the diseases severity and this finding are according to Chen et al. (2009); Calvo et al. (2007). El-Hendawy et al. (2005) reported that $R$. aquatilis can reduce the disease severity of bacterial spot of tomato under greenhouse conditions. Several investigators have concluded that the use of certain antagonistic bacteria (fluorescent Pseudomonads and Pantoea agglomerans) as resistance inducers to infection of radish plants against bacterial spot caused by $X$. campestris pv. armoraciae resulted in reduction of symptoms development on host plants (Han et al., 2000; Szczech et al., 2002).

In field experiments, severity of blossoms blight was also investigated. Data reported herein demonstrated that ASM caused a significant reduction of apple blossoms infection in seasons 2002 and 2003. Ra39 reduced significantly the amount of blight blossoms in both tested seasons. These results are in accordance with those reported by Zeller and
Zeller (1999); Laux et al. (2002). However, our results are in disagreement with those reported by Thomson et al. (1999); Buban et al. (2002), who pointed out that application of ASM on apple plant in orchards, provided unsatisfactory level of fire blight control. Also, our results reported that Ra39 more effective than ASM and this reversed with the results under greenhouse conditions this may be due to that ASM is not effect on blossom blight but affected on shoot and leaves this agree with the results of Thomson et al. (1999) who reported that there no significant effect of ASM in incidence of blossom blight from natural infection with E. amylovora. Also, may be Ra39 more affect because it increases multiplication on follower after treatments. Our results indicated that the activities of chitinase and $\beta$-1, 3-glucanase were evaluated and found a correlation between resistance and the accumulation of both enzymes activities (Tables 3, 4). Induction of PR proteins in ASM and Ra39 treated leaves agrees with the finding by Baysal and Zeller (2004) who also found increased accumulation of chitinase and $\beta-1,3$-glucanase in apple plants after treatments with ASM.

All treatments had an obvious effect on multiplication of bacteria within plants. Treated plants with ASM and Ra39 exhibited significantly lower bacterial population after 7 days from inoculation compared to untreated plants (control), generally, ASM showed the higher reduction in bacterial multiplication than the bacterium, $R$. aquatilis Ra39 after all tested inoculation periods. Such results are agreed with those reported by Roberto et al. (2002); Baysal and Zeller (2004). The effect of tested resistance inducers in reduction of bacterial population within the host cells may be due to their indirect effect on decreasing nutritional substance available to growth of the bacteria. A low nutrient concentration in the intercellular space can be a limiting factor for the growth of pathogens (Goodman et al., 1986). Also, Zeller (1998) suggested that this effect may be caused by an accumulation of anthocyanins hindering bacterial pathogenic enzyme as physiological barrier in xylem parachymas.

Accumulation of pathogenesis-related proteins (PRs) ( $\beta$ 1,3-glucanase, chitinase) after plant inoculation by certain viruses, bacteria and fungi play an important role in the physiology of induction resistance for plant diseases. (Maxson-Stein et al., 2002; Baysal and Zeller, 2004; AboElyousr et al., 2005; Abo-Elyousr et al., 2008). Results of this study revealed that application of ASM to apple shoots caused the higher chitinase activity than that of Ra39. The enzyme activity was increased after 2, 4 and 6 days from application. ASM treatment caused the higher $\beta-1,3-$ glucanase activity than that of Ra39. Maximum enzyme activity was recorded after 6 days from application and then decreased after 8 and 10 days from application. These 
results are in agreement with those reported by Own et al. (2002); Bokshi et al. (2003). However, our results are disagree with those reported by Van Loon (1997), who mentioned that PR-protein induction may not correlate with disease resistance in all plants or under certain inducing conditions. Brisset et al. (2000) tested ASM against E. amylovora and determined an enhancement of $\beta-1,3-$ glucanase activity in Golden Delicious seedlings under greenhouse conditions, the protection against fire blight was found to be around 69\%. Induced activity was mostly found to be associated with an acidic chitinase. Products of several SAR genes for example, $\beta$-1, 3-glucanase, chitinase and PR-1 proteins, have direct antimicrobial activity or are closely related to classes of antimicrobial proteins (MaxsonStein et al., 2002). Baysal and Zeller 2004 pointed that this enzymes are capable of catalyzing degradation of cell walls of plant pathogenic agents, because $\beta$-1,3-glucan and chitin are essential components of the pathogen cell walls and these enzymes catalyze hydrolysis of the corresponding substrates, thereby releasing biologically active oligosaccharides (elicitors and suppressors) capable of regulating the immune status of plant tissues. In conclusion, application of ASM and $R$. aquatilis Ra39 were effective as described herein and could be recommended for controlling the apple fire blight disease.

\section{References}

Abo-Elyousr, K. A. M. and El-Hendawy, H. H. 2008. Integration of Pseudomonas fluorescens and acibenzolar-S-methyl to control bacterial spot disease of tomato. Crop Prot. 27:1118-1124.

Abo-Elyousr, K. A., Hussein, M. A. M., Allam, A. D. A. and Hassan, M. H. A. 2008. Enhanced Onion Resistance against Stemphylium Leaf Blight Disease, Caused by Stemphylium vesicarium, by Di-potassium Phosphate and Benzothiadiazole Treatments. Plant Pathol. J. 24:171-177.

Abo-Elyousr, K. A., Nashwa, A. Sallam and Asran, M. 2005. Accumulation of defence-related enzymes and phenols in bean plants in relation to induction of systemic resistance against common blight caused by Xanthomonas campestris pv. phaseoli. Assiut J. Agric. Sci. 36:107-119.

Baysal, O. and Zeller, W. 2004. Extract of Hedera helix induces resistance on apple rootstock M26 similar to Acibenzolar-Smethyl against Fire Blight (Erwinia amylovora). Physiol. Mol. Plant Pathol. 65:5-315.

Bokshi, A. I., Morris, S. C. and Deverall, B. J. 2003. Effect of benzothiadiazole and acetyl salicylic acid on $\beta-1,3$-glucanase activity and disease resistance in potato. Plant Pathol. 52:2227.

Bradford, M. 1976. A rapid and sensitive method for the quantitation of microgram quantities of protein utilizing the principle of protein dye binding. Anal. Biochem. 72:248-250.

Brisset, M. N., Cesbron, S., Thomson, S. V. and Paulin, J. P. 2000.
Acibenzolar-S-methyl induces the accumulation of defenserelated enzymes in apple and protects from fire blight. Eur. J. Plant Pathol. 106:529-536.

Buban, T., Sallai, P., Obzsut-Truskovszky, E. and Hertelendy, L. 2002. Trial with applying chemical agents other than bactericides to control fire blight in pear orchards. Acta Hort. 590:263-268.

Calvo, J., Calvente, V., Edith, M., Orellano, D., Benuzzi, M. and Sanz, I. T., 2007 Biological control of postharvest spoilage caused by Penicillium expansum and Botrytis cinerea in apple by using the bacterium Rahnella aquatilis. Inter. J. Food Microbio. 113:251-257.

Chen, F., Li, Y., Guo, Y., Wang, J. and Min Wang, H. 2009. Biological control of grapevine crown gall: purification and partial characterisation of an antibacterial substance produced by Rahnella aquatilis strain HX2 Eur. J. Plant Pathol. 124:427437.

Colson-Hans, E. S., Allen, S. J. and Deveral, B. J. 2000. Effects of 2,6-dichloroisonicotinic acid or bentzothiadiazole on Alternaria leaf spot, bacterial blight and Verticillium wilt in cotton under field conditions. Austr. Plant Pathol. 29:170-177.

Dietrich, R. A., Lawton, K., Friedrich, L., Cade, R., Willits, M. and Maleck, K. 1999. Induced plant defense responses. Proceedings of the $2^{\text {nd }}$ Eastern shore Natural Resources Symposium 120-125.

El-Hendawy, H. H., Mohamed, E., Osman, Noha and Sorour, M. 2005. Biological control of bacterial spot of tomato caused by Xanthomonas campestris pv. vesicatoria by Rahnella aquatilis. Microbiol. Res. 160:343-352.

El-Kazzaz, S. A. 1992. The possible role of peroxidase isozyme and phenolic substances in pathogenicity of Erwinia amylovora in pear fruits. J. Agric. Sci. Mansoura Univ. 17:996-1003.

Gomez, K. A. and Gomez, A. A. 1984. Statistical Procedures for Agriculture Research, $2^{\text {nd }}$ ed. John Willey. New York, 680 pp.

Goodman, R. N., Kiraly, Z. and Wood, K. R. 1986. The Biochemistry and Physiology of Plant diseases. University of Missouri Press, Columbia, USA. 433 pp.

Han, D. Y., Coplin, L. D., Bauer, W. D. and Hoitink, H. A. 2000. A rapid bioassay for screening rhizosphere microorganisms for their ability to induce systemic resistance. Phytopathology 90:327-332.

Heitz, T., Segond, S., Kauffmann, S., Geoffroy, P., Prasad, V. and Brunner, F. 1994. Molecular characterization of a novel tobacco pathogenesis related (PR) protein a new plant chitinase/lysozyme. Mol. Gen. Genet. 245:246-54.

Kessmann, H. Oostendrop, M., Ruess, W. Staub, T., Kunz, W. and Ryals, J. 1996. Systemic activated resistance a new technology for plant disease control. Pestic. Outlook 6:1-6.

Laux, P., Baysal, Ö. and Zeller, W. 2002. Biological control of fire blight by using Rhanella aquatilis Ra39 and Pseudomonas spp. R1. Acta Hort. 590:225-230.

Maxson-Stein, K., He, Y. S., Hemmerschmidt, R. and Jones, J. A. 2002. Effect of treating apple trees with Acibenzolar-S-Methyl on fire blight and expression of pathogenesis-related protein genes. Plant Dis. 86:785-790.

Mosch, J., Mende, A., Zeller, W., Rieck, M. and Ulrich, W. 1993. 
Plant extracts with a resistance induction effect against fire blight (Erwinia amylovora). Acta Hort. 338:389-395.

Own, K. J., Green, C. D. and Deverall, B. J. 2002. A benzothiadiazole applied to foliage reduces development and egg deposition by Meloidogyne spp. in glasshouse grown grapevine roots. Austr. Plant Pathol. 31:47-53.

Paulin, J. P. 1996. Erwinia amylovora: General characteristics, biochemistry and serology. pp. 87-115. In Fire blight- the disease and causative agent Erwinia amylovora, Vanneste, J. (ed.), CABI publishing, Oxon, UK.

Roberto, B., Scarponi, L., Ferrara, M., Sidoti, P. and Bertona, A. 2002. Induction of systemic acquired resistance in pepper plants by acibenzolar-S-methyl against bacterial spot disease Eur. J. Plant Pathol. 108:41-49.

Siegrist, J., Glenewinkwl, D., Kolle, C. and Schmidtke, M. 1997. Chemically induced resistance in green been against bacterial and fungal pathogens. J. Plant Dise. Prot. 104:599-610.

Sobiczewski, P., Krupinski, G., Berczynski, S. and Basak, A. 2001. The effect of resistance inducers on the suppression of fire blight (Erwinia amylovora) on apple shoots and pear fruitlets. Phytopathol. Pol. 22:171-182.

Szczech, M. Kowalska, B. and Smokinska, U. 2002. Induction of systemic resistance in radish by pseudomonades developing in vermicompost-amended substrate. Phytopathol. Pol. 24:5766.
Thomson, S. V., Gouk, S. C. and Paulin, J. P. 1999. Efficacy of Bion (Actigard) to control fire blight in pear and apple orchards in U.S.A., New Zeland and France. Acta Hort. 489:589-595.

VanLoon, L. C. 1997. Induced resistance in plants and the role of pathogenesis-related proteins Eur. J. Plant Pathol. 103:753765.

Vanneste, J. L. 2000. Fire blight: the disease and its causative agent, Erwinia amylovora. J. Vanneste et al. ed. CAB Publ. CAB Int., Wallingford, Uk: 1-6.

Wirth, S. J. and Wolf, G. A. 1992. Micro-plate calorimetric assay for endo-acting cellulase, xylanase, chitinase, $\beta$-1, 3-glucanase and amylase extracted from forest soil horizons. Soil. Biol. Biochem. 24:511-519.

Zeller, W. 1998. Einsatz von Pflanzenstärkungsmitteln zur biologischen Bekämpfung des Feuerbrandes. Habilitationsschrift, Universität Hannover, Germany.

Zeller, W. and Brulez, W. 1987. Change in the phenol metabolism of ornamental shrubs (Cotoneaster species) infected with Erwinia amylovora. Proc. $6^{\text {th }}$. Inernat. Conf. Plant Path. Bact. Beltsville, Maryland, U.S.A., 686-694.

Zeller, W. and Laux, P. 2002. Newest Results on the Biocontrol of fire blight in Germany. Acta Hort. 590:243-246.

Zeller, W. and Zeller, V. 1999. Control of fire blight with the plant activator Bion. Acta Hort. 489:639-645. 